\title{
POTENSI VEGETASI MANGROVE SEBAGAI PAKAN LEBAH MADU DI KAWASAN HUTAN MANGROVE SURYA PERDANA MANDIRI KELURAHAN SETAPUK BESAR SINGKAWANG UTARA
}

\author{
(The Potential Of Mangrove Vegetation As Honey Bee Feed In The Mangrove Forest Area \\ Surya Perdana Mandiri Setapuk Besar Of North Singkawang Sub District)
}

\author{
Sapto Prayoga, Burhanudin, Evi wardenaar \\ Fakultas Kehutanan Universitas Tanjungpura Pontianak Jl. Daya Nasional Pontianak 78124 \\ E-mail : yogathefabregas@gmail.com
}

\begin{abstract}
Mangrove Forest has a role for the life of fauna as a source of feed and shelter for honeybees. Honeybees need feed to maintain their survival in nature, so that the availability of the feed generated by flowers in the form of nectar and pollen gives the ability of bees to breed with maximum. This research aims to obtain the type of mangrove plants and pollen, and its potential in Surya Perdana Mandiri Mangrove Forest area. The research method used is a survey method with the example tile determination Purposive Sampling. There are 10 sample compartments of $20 \times 20$ meters in 2 research lines. Based on the results of the research is known that there are 22 types of mangrove plants, based on observations, 13 of which are the source of honey bee feed, and based on the study of literatures there are 18 The potential feed bees at the highest tree level on the Api-api putih (Avicemia Marina) with an INP value of $82.17 \%$ and the smallest value Ceriop decandra $17.50 \%$ while at the highest INP stake level of Rhizopora stylosa $76.08 \%$ with flowering $83.44 \%$ while the smallest INP Ceriop decandra $22.63 \%$ with flowering 36.36\%. In the area of Mangrove Forest Setapuk Large types of honey bee feed plant available throughout the year, although in quantity varies from month to month
\end{abstract}

Keywords: bee feed, mangrove, potential, Setapuk Besar

\section{PENDAHULUAN}

Hutan mangrove secara umum didefinisikan sebagai tipe hutan yang tumbuh pada daerah pasang surut yang tergenang pada saat pasang dan bebas genangan pada saat surut yang komunitas tumbuhannya bertoleransi terhadap garam (Riwayati, 2014) dan merupakan suatu ekosistem yang mempunyai peranan penting, baik dari sisi ekologis maupun aspek sosial ekonomi. Mangrove memiliki peran bagi kehidupan fauna diantaranya sebagai sumber pakan dan tempat tinggal berbagai makhluk hidup salah satunya lebah madu
Hutan mangrove dimanfaatkan lebah madu sebagai tempat berkembang biak, bersarang dan mencari pakan, untuk makanan bunga mangrove menghasilkan nektar dan polen dimana lebah memanfaatkannya sebagai pakan, dengan semakin banyaknya jenis tanaman yang ada memberikan peluang bagi lebah untuk dapat hidup dan berkembang. Menurut (Hidayatullah 2016) Sebagian besar jenis mangrove memiliki bunga yang mengandung polen dan nektar sebagai makanan bagi koloni lebah penghasil madu, informasi ini juga diperkuat dengan adanya hasil penelitian (Virakhtamath, et al 2013) 
jenis tanaman mangrove seperti Sesuvium portulacastrum L. Avicennia officinalis L. Terminalia catappa Bruguiera gymnorrhiza, Ceriops decandra merupakan pakan bagi lebah Stingless bee, Apis dorsata Apis cerana dan Apis florea. Keragaman flora mangrove yang sebagian besar mempunyai bunga yang berpotensi sebagai pakan bagi koloni lebah sehingga dapat memberikan kemampuan koloni lebah dapat berkembang dengan maksimal serta menghasilkan madu.

Kawasan Mangrove Surya Perdana Mandiri (SPM) terletak di Kelurahan Setapuk Besar Kecamatan Singkawang Utara memiliki luas vegetasi mangrove $\pm 26,1$ ha. Kawasan ini juga memiliki kerapatan jenis, komposisi yang cukup tinggi. Di kawasan mangrove setapuk ini ditemukan jenis lebah Trigona $\mathrm{sp}$ dan Apis sp yang menumpang hidup di rongga-rongga pohon mangrove. Sumber pakan merupakan faktor pendukung utama untuk suatu kawasan dapat dijadikan tempat budidaya lebah madu. Salah satu lokasi yang dapat dijadikan tempat budidaya lebah madu yaitu kawasan Hutan Mangrove Surya Perdana Mandiri. Sementara itu, hingga saat ini belum ada laporan ataupun penelitian terkait dengan jenis tanaman penghasil nektar dan polen di kawasan mangrove SPM. Penelitian ini bertujuan untuk mendapatkan jenis tanaman mangrove penghasil nektar dan polen beserta potensinya dimana nantinya akan difokuskan pada eksplorasi dan inventarisasi jenis tanaman mangrove yang dimanfaatkan lebah madu sebagai sumber pakannya. Eksplorasi dilakukan untuk menetapkan daerah yang akan digunakan untuk lokasi budidaya lebah madu, sedangkan inventarisasi dilakukan untuk mengetahui jenis tanaman mangrove apa saja yang dijadikan sumber pakan dan tempat bersarang lebah madu tersebut. Hasil penelitian ini diharapkan dapat dijadikan sebagai dasar untuk budidaya lebah madu di Kawasan Hutan Mangrove Surya Perdana Mandiri.

\section{METODE PENELITIAN}

Penelitian dilakukan dari tanggal 01 Agustus 2019 - 30 Agustus 2019 di Kawasan Mangrove Surya Perdana Mandiri yang berada di Kelurahan Setapuk Besar Kecamatan Singkawang Utara. Peralatan yang digunakan antara lain; kamera, kompas, tali rapia, pita ukur, alat tulis, tally sheet, peta penelitian, kalkulator, GPS. Obyek dari penelitian adalah vegetasi Mangrove sumber pakan lebah.

Metode penelitian yang digunakan adalah metode survei dengan penentuan petak contoh secara Purposive Sampling dengan pengambilan data secara eksplorasi dan dianalsisis secara deskriptif. Pengambilan sampel petak contoh diambil $10 \%$ dari luas kawasan 26,1 ha, maka luas petak contoh yang diamati 2,61 ha dibagi dengan lebar sampel contoh sehingga didapatkan 10 petak contoh dengan ukuran 20 x $20 \mathrm{~m}$. Titik pusat kawasan penelitian berdasarkan pada banyaknya keberadaan lebah di lokasi penelitian. Hasil survei pendahuluan terdapat dua 
lokasi yang ditemukan banyak lebahnya, yaitu dibagian Selatan dan dibagian Utara Hutan Mangrove Surya Perdana Mandiri. Setelah ditetapkan jalur penelitian selanjutnya dibuat petak contoh dilapangan secara sistematis desain petak contoh disajikan pada Gambar 1.

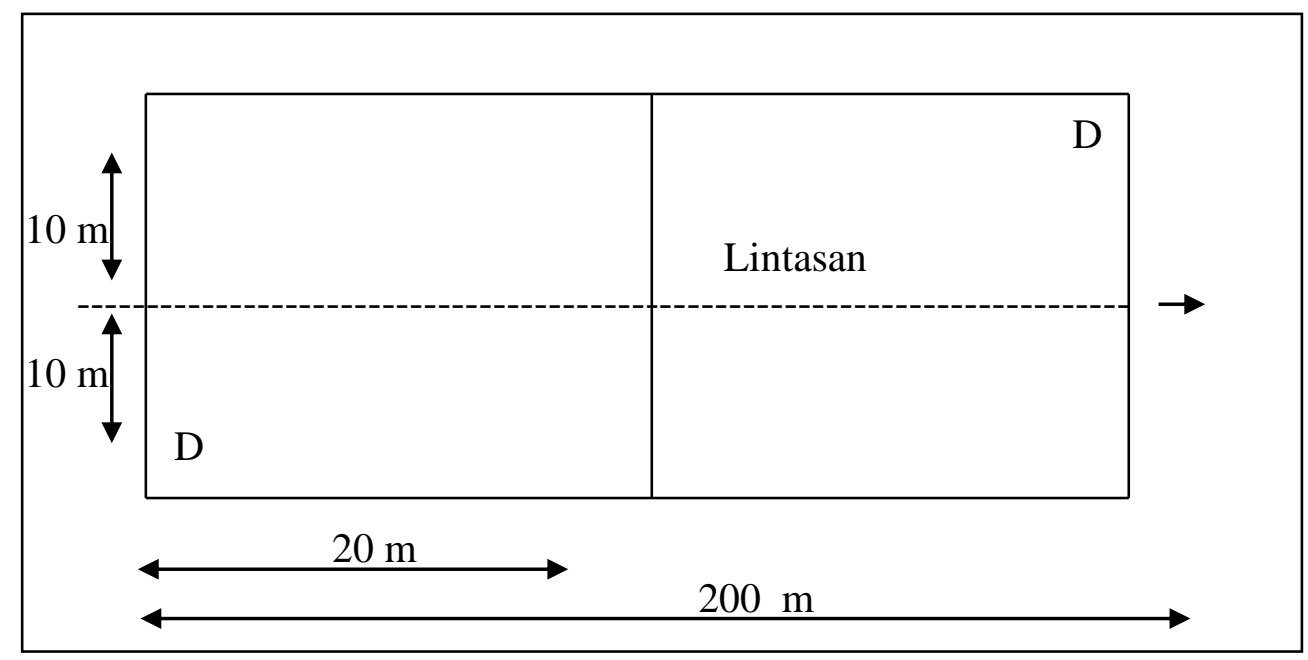

Gambar 1. Desain Petak contoh dilapangan dengan metode kombinasi (Desain sample plots in the field with sample plot methods) Source : Indriyanto, (2006)

\section{Pengumpulan Data}

Pengumpulan data dilakukan dengan mengidentifikasi tanaman penghasil nektar dan polen dilakukan dengan mengambil sampel lima buah bunga kemudian memeriksa ketersediaan nektarnya. Pemeriksaan dilakukan dengan membuka mahkota bunga, kemudian memeriksa cairan nektar pada bagian dasar bunga. Pemeriksaan ketersediaan polen dilakukan pada bagian kepala sari. Status sumber pakan lebah mangrove ditetapkan berdasarkan pada kunjungan lebah saat pengamatan langsung dilapangan. Untuk tanaman yang tidak berbunga saat penelitian dilakukan tetapi merupakan sumber pakan menurut berbagai pustaka tetap dikategorikan sebagai tanaman pakan lebah.

\section{Inventarisasi Tanaman Mangrove} Dalam Petak Contoh

Inventarisasi tanaman dilakukan dengan mencatat jenis tanaman, jumlah tanaman dan keberadaan bunga dari setiap petak contoh untuk perhitungan jumlah tanaman hanya dilakukan pada pohon dan tanaman yang berbunga. Untuk tumbuhan bahwa hanya dilakukan identifikasi jenis dan tidak dilakukan perhitungan jumlah tanaman.

\section{Pengamatan Kunjungan Lebah} Pada Tanaman

Kunjungan lebah pekerja pada suatu tanaman merupakan bentuk bahwa lebah ingin mendapatkan suatu manfaat dari tanaman berupa nektar dan polen. Salah satu manfaat yang bisa diperoleh adalah pakan lebah itu sendiri. Pengamatan dilakukan apabila terlihat lebah datang pada jenis tanaman untuk 
hinggap dan aktif menunjukkan gerakan mengambil pakan. Lebah dapat dipastikan mengambil polen bunga jika pada kakinya terkumpul polen, dan sebaliknya lebah diketahui mengambil nektar bunga dilihat dari cara perpindahannya yang cepat dari satu bunga ke bunga yang lain dan menunjukkan aktivitas mengambil nektar (Philip 1995 dalam Mulyono, et al. 2015).

Pengamatan kunjungan lebah difokuskan pada jenis lebah Trigona sp dengan kapasitas kantong dan probosis yang kecil sehingga ketika lebah terlihat mengambil nektar pergerakan tidak terlalu cepat sehingga memudahkan untuk pengamatan. Menurut Alisna, et al. (2018) Pengamatan dilakukan dengan melihat lebah yang datang pada bunga tanaman. Bunga yang mekar akan ditandai dengan cara pemberian label pada tangkai bunga tersebut. Pengamatan dimulai pada pukul 06.00 WIB dan berakhir pada pukul 18.00 WIB.

\section{Pengolahan Data}

Potensi sumber pakan lebah madu dilakukan dengan menggunakan analisis vegetasi mengidentifikasi jenis, kerapatan, frekuensi, dominasi dan INP vegetasi mangrove untuk mendapatkan sumber pakan ketersediaan melimpah. Untuk menghitung besaran parameter yang diukur dalam analisis vegetasi digunakan rumus sebagai berikut :

Kerapatan $=$

Jumlah seluruh tumbuhan suatu jenis jumlah seluruh petak contoh

Kerapatan Relatif $(\mathrm{KR})=$

$\frac{\text { Nilai kerapatan suatu jenis }}{\text { Nilai kerapatan seluruh jenis }} \times 100 \%$

Dominasi $=\frac{\text { Jumlah luas bidang dasar }}{\text { luas petak contoh }}$

Dominasi Relatif $(\mathrm{DR})=$

$\frac{\text { Dominasi dari suatu jenis }}{\text { Dominasi dari seluruh jenis }} \times 100 \%$

Frekuensi $=$

Jumlah petak contoh ditemukan semua jenis Jumlah seluruh petak contoh

Frekuensi Relatif $(\mathrm{FR})=$

$\frac{\text { Frekuensi dari suatu jenis }}{\text { Frekuensi seluruh jenis }} \times 100 \%$

Kemudian untuk masing-masing spesies dicari besarnya Nilai Indeks Penting (INP), yaitu $=\mathrm{KR}+\mathrm{DR}+\mathrm{FR}$. Mencatat data yang merupakan daftar jenis-jenis tumbuhan yang terdapat dalam suatu komunitas vegetasi yang diamati disusun sesuai abjad berdasarkan nama jenis tumbuhan dan marganya.

\section{Analisis Data}

Analisis data dinyatakkan secara deskriptif, dengan meliputi parameter kunjungan lebah dan pendekatan analisis vegetasi. 
JURNAL HUTAN LESTARI (2020)

Vol. 8 (2) : $441-453$

Tabel 1. Thally Sheet Pengumpulan data jenis tanaman pakan lebah (Thally Sheet data collection on bee feed plant types)

\begin{tabular}{lllllll}
\hline No & Jenis tanaman & $\begin{array}{l}\text { Keadaan } \\
\text { bunga }\end{array}$ & $\begin{array}{l}\text { Status } \\
\text { sumber pakan }\end{array}$ & $\begin{array}{l}\text { Frekuensi } \\
\text { kunjungan } \\
\text { lebah }\end{array}$ & $\begin{array}{l}\text { Penentuan status pakan } \\
\text { lebah }\end{array}$ & Pengamatan \\
\hline 1 & 2 & 3 & 4 & 5 & 6 & 7 \\
\hline
\end{tabular}

Keterangan $: \mathrm{n}=$ nektar, $\mathrm{p}=$ polen $\mathrm{b}=$ berbunga $\mathrm{tb}=$ tidak berbunga

$+++=$ Jumlah lebah yang mengunjungi tanaman $>7$ ekor

$++=$ Jumlah lebah yang mengunjungi tanaman 5-7 ekor

$+=$ Jumlah lebah yang mengunjungi tanaman 1-4 ekor

- $\quad=$ tidak di kunjungi oleh lebah

\section{HASIL DAN PEMBAHASAN}

\section{Tanaman Pakan Lebah}

Hasil penelitian dilapangan diketahui bahwa tanaman sumber pakan lebah berupa nektar dan polen dinyatakan pada Tabel 2. 
JURNAL HUTAN LESTARI (2020)

Vol. 8 (2) : 441 - 453

Tabel 2. Jenis tanaman mangrove sumber pakan lebah di kawasan Hutan Mangrove Surya Perdana Mandiri Setapuk Besar (Types of mangrove plants as a source of feed for bees in the Surya Perdana Mandiri Mangrove Forest area of Setapuk Large)

\begin{tabular}{|c|c|c|c|c|c|c|}
\hline \multirow{2}{*}{ No } & \multirow{2}{*}{ Jenis tanaman } & \multirow{2}{*}{$\begin{array}{c}\text { Keadaan } \\
\text { bunga }\end{array}$} & \multirow{2}{*}{$\begin{array}{c}\text { Status sumber } \\
\text { pakan }\end{array}$} & \multirow{2}{*}{$\begin{array}{c}\text { kunjungan } \\
\text { lebah }\end{array}$} & \multicolumn{2}{|c|}{ Penentuan status pakan lebah } \\
\hline & & & & & Pengamatan & Pustaka \\
\hline 1 & 2 & 3 & 4 & 5 & 6 & 7 \\
\hline 1. & $\begin{array}{l}\text { Api-api hitam } \\
\text { Avicennia lanata }\end{array}$ & $\mathrm{b}$ & - & - & & \\
\hline 2. & $\begin{array}{l}\text { Api-api putih } \\
\text { Avicennia marina }\end{array}$ & $\mathrm{b}$ & $\mathrm{n}$ & +++ & $\checkmark$ & $\begin{array}{c}\text { Susanto D, et al. } \\
\text { (2016) }\end{array}$ \\
\hline 3. & $\begin{array}{l}\text { Bakau minyak } \\
\text { Rhizopora apiculata }\end{array}$ & $\mathrm{b}$ & $\mathrm{p}$ & ++ & $\checkmark$ & $\begin{array}{c}\text { Mohammed ZN, et al. } \\
\text { (2012) }\end{array}$ \\
\hline 4. & $\begin{array}{l}\text { Bakau kurap } \\
\text { Rhizopora stylosa }\end{array}$ & $\mathrm{b}$ & $\mathrm{np}$ & +++ & $\checkmark$ & $\begin{array}{c}\text { Susanto D,et al. } \\
\text { (2016) }\end{array}$ \\
\hline 5. & $\begin{array}{l}\text { Bakau gajah } \\
\text { Rhizopora mucronata }\end{array}$ & $\mathrm{b}$ & np & +++ & $\checkmark$ & $\begin{array}{c}\text { Susanto D, et al. } \\
\text { (2016) }\end{array}$ \\
\hline 6. & $\begin{array}{l}\text { Jeruju putih } \\
\text { Acanthus ilicifolius } L \text {. }\end{array}$ & $\mathrm{b}$ & $\mathrm{n}$ & - & $\checkmark$ & Zmarlicki (1994) \\
\hline 7. & $\begin{array}{l}\text { Jeruju Ungu } \\
\text { Acanthus ebracteatus }\end{array}$ & tb & - & - & & \\
\hline 8. & $\begin{array}{l}\text { Tumok } \\
\text { Bruguiera cylindrica }(L .)\end{array}$ & $\mathrm{b}$ & - & - & $\checkmark$ & \\
\hline 9. & $\begin{array}{l}\text { Berembang } \\
\text { Sonneratia ovata }\end{array}$ & tb & $\mathrm{np}$ & - & & Li CS, et al. (2006) \\
\hline 10. & $\begin{array}{l}\text { Pidada Merah } \\
\text { Sonneratia caseolaris }\end{array}$ & $\mathrm{tb}$ & $\mathrm{np}$ & - & & Zmarlicki (1994) \\
\hline 11. & $\begin{array}{l}\text { Bakau Pensil } \\
\text { Ceriops decandra }\end{array}$ & $\mathrm{tb}$ & $\mathrm{np}$ & - & & Zmarlicki (1994) \\
\hline 12. & $\begin{array}{l}\text { Putut } \\
\text { Bruguiera gymnorrhiza (L.) }\end{array}$ & tb & $\mathrm{np}$ & - & & Zmarlicki (1994) \\
\hline 13. & $\begin{array}{l}\text { Nipah } \\
\text { Nypa fruticans }\end{array}$ & $\mathrm{b}$ & $\mathrm{np}$ & +++ & $\checkmark$ & $\begin{array}{l}\text { Susanto D, et al. } \\
\text { (2016) }\end{array}$ \\
\hline 14. & $\begin{array}{l}\text { Gelang Laut } \\
\text { Sesuvium portulacastrum (L.) }\end{array}$ & $\mathrm{b}$ & $\mathrm{np}$ & ++ & $\checkmark$ & $\begin{array}{c}\text { Krishnamurthy K } \\
\text { (1990) }\end{array}$ \\
\hline 15. & $\begin{array}{l}\text { Waru Laut } \\
\text { Thespesia populnea }(L .)\end{array}$ & $\mathrm{b}$ & $\mathrm{n}$ & + & $\checkmark$ & Venkatesan C (2011) \\
\hline 16. & $\begin{array}{l}\text { Waru Pantai } \\
\text { Hibiscus tiliaceus L }\end{array}$ & $\mathrm{b}$ & $\mathrm{n}$ & +++ & $\checkmark$ & $\begin{array}{l}\text { Rosmarlinasiah, et al. } \\
\text { (2015) }\end{array}$ \\
\hline 17. & $\begin{array}{l}\text { Sinai } \\
\text { Clerodendrum inerme }\end{array}$ & $\mathrm{b}$ & $\mathrm{n}$ & + & $\checkmark$ & Venkatesan C (2011) \\
\hline 18. & $\begin{array}{l}\text { Mengkudu } \\
\text { Morinda citrifolia L }\end{array}$ & $\mathrm{b}$ & - & - & & \\
\hline 19. & $\begin{array}{l}\text { Ketapang } \\
\text { Terminalia catappa }\end{array}$ & $\mathrm{tb}$ & $\mathrm{np}$ & - & & $\begin{array}{l}\text { Ramana V, et al. } \\
\text { (2003) }\end{array}$ \\
\hline 20. & $\begin{array}{l}\text { Serunai } \\
\text { Wedelia biflora }\end{array}$ & $\mathrm{b}$ & $\mathrm{p}$ & + & $\checkmark$ & \\
\hline 21. & $\begin{array}{l}\text { Sendayong } \\
\text { Pluchea indica }\end{array}$ & $\mathrm{b}$ & $\mathrm{p}$ & + & $\checkmark$ & Mohammed A (2019) \\
\hline 22. & $\begin{array}{l}\text { Buta-buta } \\
\text { Excoecaria agallocha }\end{array}$ & $\mathrm{b}$ & $\mathrm{np}$ & +++ & $\checkmark$ & Zmarlicki (1994) \\
\hline
\end{tabular}

Keterangan $: \mathrm{n}=$ nektar, $\mathrm{p}=$ polen $\mathrm{b}=$ berbunga $\mathrm{tb}=$ tidak berbunga $+++=$ Jumlah lebah yang mengunjungi tanaman $>7$ ekor $++=$ Jumlah lebah yang mengunjungi tanaman 5-7 ekor $+=$ Jumlah lebah yang mengunjungi tanaman 1-4 ekor $-=$ Tidak di kunjungi oleh lebah 
Pengamatan dilapangan ditemukan 22 jenis tanaman, 13 diantaranya merupakan jenis tanaman sumber pakan lebah madu, 5 jenis tanaman sedang tidak berbunga dan 4 jenis tanaman lainnya tidak diketahui. Jenis-jenis pakan lebah madu sebagai berikut; Apiapi putih (Avincennia marina) Jeruju putih (Acanthus ilicifolius L), Waru laut (Thespesia populnea L.) Waru pantai (Hibiscus tiliaceus L), Sinai (Clerodendrum inerme) Bakau minyak (Rhizopora apiculata), Serunai (Wedelia biflora), Sendayong (Pluchea indica) Buta-buta (Excoecaria agallocha), Gelang laut (Sesuvium portulacastrum L.), Bakau gajah (Rhizopora Mucronata), Nipah (Nypa fruticans), dan Bakau kurap (Rhizopora stylosa). Untuk jenis tanaman yang bukan pakan lebah Api-api hitam (Avicennia lanata), Tumok (Bruguiera cylindrica L.), dan Mengkudu (Morinda citrifolia $L$ ). Pengamatan hanya terbatas pada saat tanaman tersebut berbunga, Sedangkan untuk tanaman yang tidak berbunga namun merupakan sumber pakan lebah berupa nektar dan polen adalah Ketapang (Terminalia catappa), Berembang (Sonneratia ovata), Pidada Merah (Sonneratia caseolaris), Putut (Bruguiera gymnorrhiza (L.) Lamk), dan Bakau pensil (Ceriops decandra).

Kunjungan lebah dari satu bunga ke bunga yang lain meningkat jika nektar bunga cukup tinggi, sebaliknya bila kuantitas nektar rendah maka frekuensi kunjungan cenderung turun, lebah menyukai polen karena kandungan proteinnya dan menyukai nektar karena kadar gulanya, semakin banyak nektar mengandung gula maka lebah akan sering mengunjungi bunga tersebut (Rizki, et al. 2017). Lebah akan memilih satu macam bunga hingga persediaannya berkurang. Jenis tanaman tersebut memiliki pola dan waktu pembungaan yang berbeda sehingga variasi kunjungan lebah tergantung spesies tanaman, jumlah tanaman dan ukuran bunga dimana faktor-faktor eksternal seperti suhu, cahaya, kelembaban, unsur hara dan faktor internal fitohormon dan genetik berbeda pada setiap tanamaan. Selain itu, lama pembungaan dan komposisi kimia nutrien nektar yang dihasilkan juga berbeda (Pacini dan Nicolson, 2007 dalam Agussalim, et al. 2017) lebah beraktifitas untuk mencari pakan pada pagi hari dengan jumlah yang lebih banyak dibandingkan siang atau sore hari, karena Sekresi nektar pada tanaman terjadi pada saat bunga mekar pertama kali (Tricahyadi 2007 dalam Ridwan, et al. 2016). Sehingga kebutuhan pakan berupa nektar dan polen akan melimpah pada waktu pagi.

\section{Persentase Tanaman Penghasil Nektar dan Polen}

Persentase tanaman penghasil nektar dan polen dilakukan untuk mendapatkan jenis pakan yanng dominan pada lokasi penelitian dimana lebah akan lebih aktif mengambil nektar atau polen berdasarkan pada kelimpahaannya 


\section{Tanaman Sumber Nektar dan Polen}

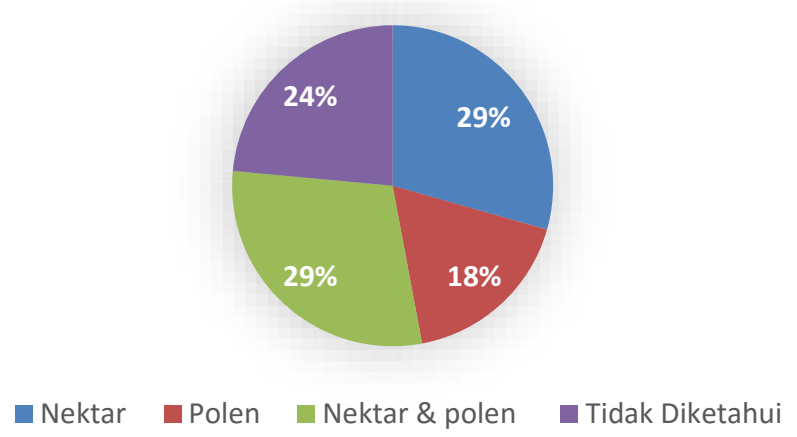

Gambar 2. Persentase tanaman penghasil nektar dan polen (Percentage of nektar and pollen producing plants)

Gambar 2. menunjukkan bahwa tanaman penghasil nektar yang berhasil di identifikasi adalah Api-api putih (Avincennia marina), Jeruju putih (Acanthus ilicifolius L), Waru laut (Thespesia populnea L.) dan Waru pantai (Hibiscus tiliaceus L), Sinai (Clerodendrum inerme) dengan persentase $29 \%$, sedangkan untuk tanaman penghasil polen saja yang teridentifikasi yakni Bakau minyak (Rhizopora apiculata), Serunai (Wedelia biflora), dan Sendayong (Pluchea indica) dengan persentase $18 \%$. Jenis-jenis tanaman penghasil kedunya (nektar dan polen) adalah Buta-buta (Excoecaria agallocha), Gelang laut (Sesuvium portulacastrum L.), Bakau gajah (Rhizopora Mucronata), Nipah (Nypa fruticans), dan Bakau kurap (Rhizopora stylosa) dimana merupakan jenis yang dominan dengan persentase $29 \%$, lebah terkadang mengambil polen dan nektar dalam waktu bersamaan. Jenis tanaman lainnya tidak diketahui Api-api hitam (Avicennia lanata), Tumok (Bruguiera cylindrica L.), dan Mengkudu (Morinda citrifolia L) dengan persentase $24 \%$. Penyebaran Jenis tanaman pada setiap petak contoh dilokasi tidak merata tanaman yang hampir merata pada setiap petak contoh antara lain Avincennia marina, Rhizopora stylosa dan Rhizopora mucronata nektar dan polen diatas menunjukkan persenntase yang sama dengan kuantitas yang berbeda pada setiap tanaman.

\section{Potensi Pakan Lebah Madu}

\section{Potensi tingkat pohon}

Pengukuran potensi pakan lebah pada vegetasi mangrove dilakukan pada tingkat pohon dan pada tingkat pancang dengan menghitung - Indeks Nilai Penting (INP). INP menujukkan kepentingan suatu jenis tumbuhan serta peranannya dalam suatu komunitas, dimana nilai penting pada vegetasi tingkat pohon dan pancang didapat dari hasil penjumlahan Kerapatan Relatif (KR), Frekuensi Relatif (FR), dan Dominansi Relatif (DR), untuk pembungaan di tingkat pohon sudah terjadi $100 \%$ karna faktor-faktor fitohormon yang mendukung sehingga tidak dilakukan perhitungan prosen. 
Hasil pengukuran jenis tanaman pada tingkat pohon tanaman yang memiliki INP tertinggi adalah Avincennia marina
$82,17 \%$ dan yang terkecil Ceriops decandra $17,50 \%$.

Tabel 3. Indeks Nilai Penting Pada Tingkat Pohon Sumber Pakan Lebah (Important value index at the level of the bee feed source tree)

\begin{tabular}{lrrrr}
\hline \multicolumn{1}{c}{ Jenis tanaman } & KR & \multicolumn{1}{c}{ DR } & \multicolumn{1}{c}{ FR } & \multicolumn{1}{c}{ INP } \\
\hline Avicennia marina & 38,46 & 13,28 & 30,43 & 82,17 \\
Ceriops decandra & 3,846 & 9,308 & 4,34 & 17,50 \\
Hibiscus tiliaceus L & 25 & 16,60 & 30,43 & 72,03 \\
Thespesia populnea $($ L.) & 5,76 & 17,87 & 13,04 & 36,69 \\
Terminalia catappa & 9,61 & 16,10 & 13,04 & 38,76 \\
Excoecaria agallocha & 17,30 & 26,82 & 8,69 & 52,82 \\
Jumlah & $\mathbf{1 0 0}$ & $\mathbf{1 0 0}$ & $\mathbf{1 0 0}$ & $\mathbf{3 0 0}$ \\
\hline
\end{tabular}

Tanaman Api-api putih (avincennia marina) memiliki kerapatan tertinggi 50 pohon/ha dengan (KR) $38,46 \%$ sedangkan Ceriops decandra memiliki kerapatan terendah 5 pohon/ha dengan (KR) 3,84\%, dominansi tertinggi yaitu Buta-buta (Excoecaria agallocha) 0,083 dengan (DR) 26,82\% dan dominansi terendah Ceriop decandra 0,029 dengan (DR) 9,30\%. Frekunsi tertinggi Avincennia marina dan Hibiscus tiliaceus $L$ frekuensi 0,7 dengan FR $30,43 \%$.

\section{Potensi Tingkat tiang}

Pada tingkat pancang selain dihitung INP juga akan di bagi prosen Tabel 4. Indeks Nilai Penting Tingkat Pancang (Important value indexes at the stake level)

\begin{tabular}{lrrrrrr}
\hline \multicolumn{1}{c}{ Jenis tanaman } & \multicolumn{1}{c}{ KR } & \multicolumn{1}{c}{ DR } & \multicolumn{1}{c}{ FR } & INP & $\begin{array}{c}\text { Keadaan } \\
\text { bunga }\end{array}$ & $\begin{array}{c}\text { persentase } \\
\text { berbunga \% }\end{array}$ \\
\hline Avicennia marina & 12,62 & 15,00 & 13,95 & 41,57 & $\mathrm{~b}$ & 46,15 \\
Rhizopora apiculata & 8,98 & 5,22 & 18,60 & 32,80 & $\mathrm{~b}$ & 37,83 \\
Rhizopora stylosa & 53,51 & 1,55 & 20,93 & 76,00 & $\mathrm{~b}$ & 83,44 \\
Rhizopora mucronata & 16,62 & 2,56 & 18,60 & 37,79 & $\mathrm{~b}$ & 83,21 \\
Ceriops decandra & 6,67 & 6,65 & 9,30 & 22,63 & $\mathrm{~b}$ & 36,36 \\
Thespesia populnea $($ L.) & 0,12 & 21,10 & 2,32 & 23,55 & $\mathrm{tb}$ & 0 \\
Hibiscus tiliaceus L & 0,97 & 23,55 & 9,30 & 33,83 & $\mathrm{~b}$ & 50 \\
Terminalia catappa & 0,48 & 24,33 & 6,97 & 31,79 & $\mathrm{tb}$ & 0 \\
\hline Jumlah & $\mathbf{1 0 0}$ & $\mathbf{1 0 0}$ & $\mathbf{1 0 0}$ & $\mathbf{3 0 0}$ & & \\
\hline
\end{tabular}

pada jenis tanaman yang berbunga ini dilakukan karna menurut (Tendra, et al 2014) pada umur 3-4 tahun jenis tanaman mangrove akan terjadi pembungaan dimana pada umur yang efektif tanaman tersebut belum melampau masa tingkat pohon, sehingga pada lokasi penelitian tidak semua tingkat pancang menghasilkan bunga dan menginjak umur yang maksimal untuk berbunga, nantinya hasil tersebut akan didapatkan kelimpahan bunga berdasarkan pada pembungaan tanaman.

$$
\text { Keterangan : } \begin{aligned}
\mathrm{b} & =\text { berbunga } \\
\mathrm{tb} & =\text { tidak berbunga }
\end{aligned}
$$


Pada tingkat pancang jenis tanaman paling dominan adalah Rhizopora stylosa dengan INP tertinggi 76,08\% dan untuk jenis pancang terendah Ceriop decandra dengan INP 22,63\%. Persentase berbunga tertinggi Rhizopora stylosa $83,44 \%$. Pengamatan terbatas dilakukan hanya pada saat penelitian bunga sedang mekar. Pada Tabel 3 dan 4. menunjukkan jenis-jenis yang dominan terdapat dalam jumlah yang banyak dan dengan ukuran yang lebih besar. Banyaknya jenis yang terdapat di kawasan hutan mangrove menyebabkan musim berbunga bervariasi, sehingga setiap waktu ada jenis tumbuhan berbunga namun tidak dalam jumlah yang banyak, kondisi demikian menyebabkan ketersediaan pakan bagi lebah terutama bagi lebah yang dibudidayakan Trigona sp tidak mencukupi dalam setiap waktu hal tersebut terjadi karena kemampuan terbang dari jenis lebah ini hanya sekitar $600 \mathrm{~m}$ (Amano, et al. 2001 dalam Yanto, et al. 2016). Kegiatan budidaya lebah madu Trigona sp. dapat dilakukan di sekitar kawasan hutan yang berdampingan dengan lahan perkebunan dengan jumlah bunga yang cukup banyak pada Kawasan Utara Hutan Mangrove.

\section{PEMBAHASAN}

Potensi pakan lebah di dalam kawasan Hutan Mangrove Setapuk Besar diamati pada dua areal kawasan bagian Selatan dan Utara dengan memotong tegak lurus garis pantai. Pada dua areal kawasan ditemukan berbagai macam jenis tanaman yang dimanfaatkan oleh lebah, jenis tanaman tersebut diantaranya memiliki bunga yang dapat menghasilkan nektar dan polen, kondisi alam yang memungkinkan membuat lebah dapat berkembang dengan baik, diantaranya; ketersediaan air, sumber pakan dan Stabilitas bakau memberikan perlindungan dari badai sehingga lebah akan aktif untuk beraktifitas dan berkembang biak, inventarasi ditemukan 23 sarang lebah terdiri dari jenis lebah Apis sp dan Trigona sp yang hidup dirongga-rongga kayu, melimpahnya lebah pada lokasi memungkinkan lokasi tersebut memiliki daya dukung yang baik. Kondisi ini juga terlihat pada kawasan Utara yang hampir sebagian tanaman berbunga sepanjang tahun, pada areal kawasan Selatan tanaman lebih bervariasi sehingga, pakan lebah madu dapat selalu tersedia dikarenakan berbedanya masa berbunga, kebutuhan pakan lebah dapat dicukupi oleh tanaman yang lainnya.

Kelimpahan tumbuhan mempengaruhi variasi waktu dan kunjungan lebah, dimana pada lokasi penelitian kunjungan lebah lebih aktif pada tanaman yang dominan, kunjungan lebah pada bunga saat mencari makan menunjukkan perilaku tertentu yang dipengaruhi oleh kuantitas dan kualitas nektar pada bunga. Kunjungan lebah dari satu bunga ke bunga yang lain meningkat jika nektar bunga cukup tinggi, sebaliknya bila kuantitas nektar rendah maka frekuensi kunjungan cenderung turun, lebah akan memilih 
satu macam bunga hingga persediaannya berkurang. (Amir, et al.1986) sifat-sifat tanaman yang berbeda satu sama dengan yang lainnya dalam warna, bentuk, aroma, produksi nektar dan sebagainya. Perbedaan sifatsifat tersebut menyebabkan daya tarik lebah madu terhadap bunga juga berbeda-beda.

Adanya variasi masa berbunga menunjukkan bahwa harus ada perhatian tentang jenis-jenis tanaman yang berbunga pada waktu tertentu serta tanaman-tanaman yang berpotensi sebagai pakan bagi lebah sehingga usaha ternak lebah madu memiliki peluang untuk dikembangkan. Usaha ini dapat didukung dengan pemanfaatan lokasi-lokasi yang berpeluang untuk dilakukan budidaya lebah madu.

\section{KESIMPULAN}

Berdasarkan penelitian yang telah dilakukan di kawasan hutan mangrove Kelurahan Setapuk Besar Kecamatan Singkawang Utara Kota Singkawang dapat disimpulkan bahwa

1. Terdapat 22 jenis tanaman mangrove, 13 jenis diantaranya merupakan sumber pakan lebah berupa nektar dan polen ataupun keduanya. Tanaman penghasil nektar yang berhasil diidentifikasi Api-Api putih (Avincennia marina) Jeruju putih (Acanthus ilicifolius L), Waru laut (Thespesia populnea L.) dan Waru pantai (Hibiscus tiliaceus L), Sinai (Clerodendrum inerme) untuk tanaman penghasil polen saja yang teridentifikasi Bakau minyak (Rhizopora apiculata), Serunai (Wedelia biflora), dan Sendayong (Pluchea indica). Jenis-jenis tanaman penghasil kedunya (nektar dan polen) Buta-buta (Excoecaria agallocha), Gelang laut (Sesuvium portulacastrum L.), Bakau gajah (Rhizopora Mucronata), Nipah (Nypa fruticans), dan Bakau kurap (Rhizopora stylosa).

2. Potensi pakan lebah INP tertinggi adalah Api - api putih ( Avicennia marina) dengan nilai $82,17 \%$ dan nilai INP terkecil pada jenis Ceriop decandra17,50\%. Pada tingkat pancang INP tertinggi adalah Rhizopora stylosa76,08\% dengan pembungaan $83,44 \%$ sedangkan INP terkecil Ceriop decandra $22,63 \%$. dengan pembungaan $36,36 \%$. Bunga tersedia sepanjang tahun, walaupun secara kuantitas bervariasi dari bulan ke bulan.

\section{SARAN}

1. Perlu dilakukan penelitian lanjutan mengenai sumber pakan yang disukai oleh lebah madu sebagai rekomendasi tanaman yang diusahakan untuk pengembangan budidaya lebah madu .

2. Dapat dilakukan budidaya lebah madu terutama lebah madu Trigona sp sehingga selain mendapatkan penghasilan secara ekonomi juga memberikan manfaat untuk tanaman sebagai agen polinator.

\section{UCAPAN TERIMAKASIH}

Penulis mengucapkan terimakasih kepada pihak pengelola Kawasan Hutan Mangrove Setapuk Besar yang telah 
memberikan izin lokasi peneltian, rekan-rekan kerja yang telah membantu baik dalam pelaksaanaan pengambilan data dan hingga terselesainya peneelitian ini sehingga dapat ditungkan dalam bentuk tulisan.

\section{DAFTAR PUSTAKA}

Agussalim, Agus A, Umami N, Budisatria IGS. 2017. Variasi jenis tanaman pakan lebah madu sumber nektar dan polen berdasarkan ketinggian tempat di Yogyakarta. Buletin Peternakan 41(4): 448-460

Alisna RY, Jasmi, Nursyahra. 2018. Aktivitas Kunjungan Lebah Trigona spp. (Hymenoptera: Meliponidae) Pada Tanaman Mentimun (Cucumis sativus L.)Di Dua Ketinggian Di Sumatera Barat. Repository STKIP PGRI Sumatera Barat: 1-7

Hidayatullah M. 2016. Madu Mangrove Hasil Hutan Bukan Kayu Potensial. Warta Cendana: Environment and forestry Research and development institute of kupang. Edisi IX No. 2:1-5.

Indriyanto. 2006. Ekologi Hutan. Penerbit PT Bumi Aksara. Jakarta.

Krtshnamurthy K. 1990. The Apiary Of The Mangroves. WeIland Ecology and Management: Case Sludies, India: $135-140$

Li SC, Wang YF, Bera S, Yao YF. 2006. Nectar and Pollen Sources for Honey bee (Apis cerana cerana Fabr.) in Qinglan Mangrove Area, Hainan Island: China Journal of Integrative
Plant Biology 48(11): 1266 1273

Mulyono, Susdiyanti T, Supriono B. 2015. Kajian Ketersediaan pakan lebah madu lokal (Apis cerana Fabr.). Jurnal Nusa Sylva .2: 1826

Mohamed ZN, Ghazi R, Azmi AW. 2012. Importance of Carpenter Bee, Xylocopa varipuncta (Hymenoptera: Apidae) as Pollination Agent for Mangrove Community of Setiu Wetlands, Terengganu Malaysia. Sains Malaysiana 41(9): 1057-1062

Mohammed A, Krishnan TK, Soon MJ, Vikram P, Selvaraju K. 2019. Melissopalynological, physicochemical and antioxidant properties of honey from West Coast of Malaysia. J Food Sci Technol 56(5):2508-2521.

Profil Kelurahan. 2017. Profil Kelurahan Setapuk Besar Kecamatan Singkawang Utara. Singkawang.

Ridwan M, Jasmi, Hidayat Y. 2016. Volume Nektar dan Berat Polen Tumbuhan sumber pakan Apis cerana fabr. Di patalangan kabupaten padang pariaman. Repository STKIP PGRI Sumatera Barat: 1-4

Ramana VPS, Reddi SC, Atluri BJ. 2003. Breeding and polination systems in the indian almond tree Terminalia catappa Linn. Eco, env, \& cons. 9 (3): 331-335

Rosmarlinasiah, Malamassam D, Paembonan S, Yusuf Y. 2015. Resource Potential Analysis Of Honey Bee Feed Apis Dorsatain Mountain Tinanggo Kolaka. 
International Journal Of Scientific \& Technology Research 313-318

Riwayati. 2014. Manfaat Dan Fungsi Hutan Mangrove Bagi Kehidupan. Jurnal Keluarga Sehat Sejahtera 12 (24): 17-24

Susanto D, Syafrizal, Wibowo PE. 2016. Jenis tumbuhan sumber nektar lebah Apis dorsata fabr. Dari desa bumi harapan dan desa Bukit Raya Kecamatan Sepaku Kalimantan Timur, Bioprospek 11 (1): 54-645

Tendra R, Pratomo A, Zulfikar A. 2014. Tingkat resiliensi mangrove berdasarkan tingkat bunga dan buah studi kasus Rhizophora mucronata di desa dompak, Tangjungpinang - Kepulauan Riau. Jurnal Reka: 1-10

Venkatesan

C.

2011. Melissopalynological studies on mangrove honeys from Sunderbans (Bangladesh) and
Little Andaman (India). Current Science, 100 (9): 1290-1293

Viraktamath S, Fakrudin B, Vastrad AS, Mohankumar, Editor. 2013. Morphometry And Phylogeography Of Honey Bees And Stingless Bees In India. Network Project On Honey bees and Stingless bees. Departement of Agricultural Entomology University Of Agricultural Sciences Dharward 580 005, Karnataka, India.

Yanto SH, Yoza D, Budiani ES. 2016. Potensi Pakan Trigona Spp. Di Hutan Larangan Adat Desa Rumbio Kabupaten Kampar. JOM Faperta UR 3(2): 1-7

Zmarlicki, C. B. 1994. Integrated Resource Development of the Sundarbans Reserved Forests. Draft Final report on the Development of Apiculture. 